\title{
Is the Outcome Indicator "3rd/4th Degree Perineal Tear in Spontaneous Singleton Births" a Reliable Quality Parameter in Obstetrics?
}

\section{Ist der Ergebnisindikator „Dammriss Grad III/IV bei spontanen Einlingsgeburten“ ein zuverlässiger geburtshilflicher Qualitätsparameter?}

Authors

Affiliations
H. B. G. Franz ${ }^{1}$, C. W. J. Erxleben ${ }^{2}$

${ }^{1}$ Frauenklinik Klinikum Braunschweig, Braunschweig

${ }^{2}$ Charité Universitätsmedizin Berlin, Berlin

Key words
delivery
fecal incontinence
tear
external anal sphincter
quality
Schlüsselwörter
Geburt
anale Inkontinenz
Dammriss
externer analer Sphinkter

Deutschsprachige Zusatzinformationen online abrufbar unter: www.thieme-connect.de/ ejournals/toc/gebfra

\section{Bibliography}

Dol http://dx.doi.org/ 10.1055/s-0035-1545703

Geburtsh Frauenheilk 2015; 75 145-147 @ Georg Thieme Verlag KG Stuttgart · New York . ISSN 0016-5751

\section{Correspondence}

PD Dr. med.

Heiko B. G. Franz

Frauenklinik Klinikum

Braunschweig

Celler Straße 38

38114 Braunschweig

h.franz@

klinikum-braunschweig.de

\section{Abstract}

$\nabla$

Obstetric sphincter damage is the most common cause of fecal incontinence in women. Between one-third and two-thirds of women who sustain a recognized third-degree tear during delivery subsequently suffer from fecal incontinence. We should therefore try to reduce the rate of highgrade tears as much as possible. But this rate can only be used as an outcome indicator for the quality of obstetric departments if the recognition and classification of sphincter injury is similar across departments in different hospitals.

\section{Introduction \\ $\nabla$}

Injury to the anorectal sphincter complex during vaginal birth is a significant risk factor for anal incontinence in women.

Between one and two thirds of women who sustained a third degree tear (classification based on [1] and [2]) detected immediately after delivery suffer from symptoms of anal incontinence [10]. In women who present with persistent symptoms of incontinence postpartum or who go on to develop anal incontinence at a later stage after delivery, the incidence for a defect of the external anal sphincter (EAS) muscle is $90 \%$ while the incidence for a defect of the internal anal sphincter (IAS) muscle is $65 \%$ [3].

One of the aims of obstetric care must therefore be to reduce the rates of high-grade perineal tears as much as possible. In the chapter on Epidemiology, the guideline of the German Society for Gynecology and Obstetrics (DGGG) on the management of 3rd and 4th degree tears after vaginal delivery [4] therefore lists the odds ratios for the different risk factors, the factors which reduce

\section{Zusammenfassung \\ $\nabla$}

Eine Verletzung des analen Sphinkters stellt einen wesentlichen Risikofaktor für die Entwicklung einer analen Inkontinenz bei Frauen dar. Ein bis zwei Drittel der Frauen, bei denen unmittelbar nach der Entbindung ein Dammriss (DR) Grad III festgestellt wird, leiden an analen Inkontinenzsymptomen. Eine möglichst niedrige Rate höhergradiger Dammrisse ist deshalb anzustreben. Diese Rate ist als Ergebnisindikator zur Beschreibung der Qualität einer geburtshilflichen Abteilung aber nur dann verwendbar, wenn eine vergleichbare Qualität der Wahrnehmung und Klassifizierung von analen Sphinkterverletzung in den Abteilungen besteht.

the risk and the extent to which obstetric measures can change the rate of high-grade perineal tears.

\section{Assessment for Quality Assurance $\nabla$}

The indicator set "3rd or 4th degree perineal tear" is used in Germany as a quality indicator for clinical area 16/1 (Obstetrics) [5]. The observed rate of 3rd and 4th degree perineal tears is calculated based on the number of documented 3rd and 4th degree perineal tears (numerator) in relation to all fully documented singleton births recorded in the Obstetrics score QI-ID 51181 (denominator). Since 2011, calculations have additionally included risk adjustment. The selected regression coefficients were risk factors recorded in the quality assurance documentation. Factors include maternal height, birth weight of the child, maternal age at delivery, and parity. Logistic regression analysis was used for risk adjustment. The reference range calculated for 2013 for this risk-adjusted indicator was $\leq 2.25$. 
For the risk adjustment, only 2 of the 10 risk factors listed in the new DGGG guideline on the management of high-grade perineal tears in spontaneous singleton births [4] were considered in the analysis.

\section{Detection of High-grade Tears}

$\nabla$

Obvious injuries of the anal sphincter are detected on clinical examination after vaginal delivery in between 1.5 and $9 \%$ of cases [3].

It should be noted that the detection rate for high-grade tears depends on a number of different factors. Increased vigilance on the part of the examiner with regard to high-grade injuries can already increase the number of detected tears [6]. Thus, the generally increased incidence of high-grade tears reported in the last few years is ascribed primarily to improved rates of detection [19]. Particularly women who have sustained only a partial tear of the anal sphincter (subgroup $3 \mathrm{~A}$ according to the classification of Sultan et al. [2]) require a "trained eye" to detect these injuries and ensure that they receive the necessary surgical treatment. In their study, Andrews et al. [7] showed that misclassification of the extent of injury to the anal sphincter complex occurred in $87 \%$ of cases delivered by midwives, $27 \%$ of cases assisted by junior doctors in training, $14 \%$ of cases treated by specialists and in only $1 \%$ of cases delivered by clinicians who had been specially trained in this area. In addition to clinical experience, recognition of perineal trauma is made more difficult by blood at the site of injury or significant tissue edema [8].

The prevalence of sphincter injury is much higher if additional diagnostic tools are used such as endoanal ultrasound or anal manometry. Using 2-dimensional endoanal ultrasound carried out postpartum, Sultan and colleagues [9] found that up to $35 \%$ of women had an anal sphincter defect after uncomplicated vaginal birth. Several studies have shown that postpartum use of endoanal ultrasound revealed occult anal sphincter defects in $12-44 \%$ of primiparous women after vaginal birth (cf. [10]). The wide variation in the reported incidence of occult sphincter injury has been attributed to differences in ultrasound differentiation between defects of the puboanal muscle and the transverse perineal muscles from true EAS defects [11]. In this study by Williams et al., use of an improved imaging technique, 3-dimensional endosonography, resulted in the detection of occult sphincter defects in $11 \%$ of cases, a prevalence which appears to be relatively close to the real incidence as reported by Dudding and colleagues [10].

It must be concluded that the documented numbers of highgrade perineal tears which are used to calculate the outcome indicators (see above) depend very much on the personal willingness to investigate, the individual level of training and the local site of injury at assessment, and therefore cannot be considered a reliable variable.

\section{Prediction and Prevention of High-grade Tears in Spontaneous Singleton Deliveries \\ $\nabla$}

Despite numerous studies, it has not been possible to date to develop a risk-scoring system which can be used prior to delivery to identify patients who have an increased risk of sustaining an anal sphincter injury during vaginal birth [12]. Risk estimation curves based on estimated fetal birth weight on prepartal ultrasound and maternal height could be used to predict the likelihood of perineal trauma [13]. But the current data has not yet been taken into account in the new DGGG guideline [4].

There are also currently no real evidence-based measures which could be used to prevent high-grade tears in spontaneous singleton births. The mother's position during birth was not found to have any influence on the risk of high-grade intrapartal birth trauma [14].

Prolonged second-stage labor has been associated with an increased risk of anal sphincter injury [15]. One third of women with second-stage labor of more than 4 hours sustain a clinically verified 3rd or 4th degree tear. However, measures to curtail second-stage labor such as uterine fundal pressure (the Kristeller maneuver) or early active pushing by the patient do not reduce the risk.

A training program specially designed to improve perineal support and reduce serious perineal injury appears to have had a positive effect [16].

The data on the use of episiotomies as a preventative measure against high-grade perineal tear is inconsistent. While median episiotomies increase the risk of 3rd and 4th degree tears, a restrictive use of mediolateral episiotomy appears to be acceptable $[4,17,18]$.

Overall, it must be concluded that to date there is no definite way of identifying those patients prepartum who have a higher risk of anal sphincter injury and who would potentially benefit from cesarean section as an alternative mode of delivery. Only training programs to improve perineal support and a restrictive use of mediolateral episiotomy could have a positive impact on reducing the rate of 3rd and 4th degree perineal tears.

\section{Conclusion \\ $\nabla$}

Injury of the anorectal sphincter complex results in fecal incontinence in more than one third of women. One of the aims of obstetric care must therefore be to reduce the rate of high-grade perineal tears as much as possible.

As the rate of high-grade perineal tears depends very much on the personal willingness to investigate, the individual level of training and the local site of injury at assessment, it cannot therefore be considered as a variable which reliably reflects the quality of an obstetrical department.

Before and during delivery the ability of midwives and obstetricians to influence the rate of high-grade perineal tears directly is limited, with the possible exception of a restrictive use of episiotomies.

Implementing changes to bring down high rates of the risk-adjusted outcome indicator "ratio of observed to expected rate of 3rd and 4th degree perineal tears in spontaneous singleton births" are likely to result in only very limited improvements. The validity and significance of this outcome indicator should therefore be questioned and not just when outcomes are abnormally high.

\section{Conflict of Interest}

$\nabla$

H.B.G. Franz and C.W.J. Erxleben declare that they have no conflict of interest. 


\section{References}

1 Cunningham FG, Leveno K, Bloom S. Williams Obstetrics. 23rd ed. New York: McGraw-Hill Professional; 2010

2 Sultan AH, Thakar R, Fenner DE, eds. Perineal and anal Sphincter Trauma. London: Springer; 2007

3 Nichols CM, Nam M, Ramakrishnan $V$ et al. Anal sphincter defects and bowl symptoms in women with and without recognized anal sphincter trauma. Am J Obstet Gynecol 2006; 194: 1450-1454

4 Aigmueller T, Bader W, Beilecke $K$ et al. Management of 3rd and 4th degree perineal tears after vaginal birth. German guideline of the German Society of Gynecology and Obstetrics (AWMF Registry No. 015/079, October 2014). Geburtsh Frauenheilk 2015; 7: 137-144

5 Aqua-Institut GmbH. Qualitätsindikatoren Modul 16/1 - Geburtshilfe. Göttingen: Eigenverlag; 2013

6 Groom KM, Paterson-Brown S. Can we improve on the diagnosis of third degree tears? Eur J Obstet Gynaecol Reprod Biol 2002; 101: 19-21

7 Andrews $V$, Sultan AH, Thakar $R$ et al. Occult anal sphincter injuries myth or reality? BJOG 2006; 113: 195-200

8 Fernando RJ, Sultan AH, Radley $S$ et al. Management of obstetric anal sphincter injury: a systematic review and national practice survey. BMC Health Serv Res 2002; 2: 9

9 Sultan AH, Kamm MA, Hudson CN. Anal sphincter function after delivery. N Engl J Med 1993; 329: 1905-1911

10 Dudding TC, Vaizey CJ, Kamm MA. Obstetric anal sphincter injury: incidence, risk factors, and management. Ann Surg 2008; 247: 224-237
11 Williams AB, Bartram CI, Halligan S et al. Anal sphincter damage after vaginal delivery using three-dimensional endosonography. Obstet Gynecol 2001; 97: 770-775

12 Williams A, Tincello DG, White $S$ et al. Risk scoring system for prediction of obstetric sphincter injury. BJOG 2005; 112: 1066-1069

13 Gudmundsson S, Henningsson AC, Lindquist P. Correlation of birth injury with maternal height and birthweight. BJOG 2005; 112: 764-767

14 Eason E, Labrecque $M$, Wells $G$ et al. Preventing perineal trauma during childbirth: a systematic review. Obstet Gynecol 2000; 95: 464-471

15 Cheng YW, Hopkins LM, Caughey AB. How long is too long: does a prolonged second stage of labor in nulliparous women affect maternal and neonatal outcomes? Am J Obstet Gynecol 2004; 192: 1702-1706

16 Laine K, Skjedestad FE, Sandvik L. Incidence of obstetric anal sphincter injuries after training to protect the perineum: cohort study. BMJ Open 2012; 2: e001649

17 Carroli G, Mignini L. Episiotomy for vaginal birth. Cochrane Database Syst Rev 2009; 1: CD000081

18 Wheeler TL 2nd, Richter HE. Delivery method, anal sphincter tears and fecal incontinence: new information on a persistent problem. Curr Opin Obstet Gynecol 2007; 19: 474-479

19 Gurol-Urganci I, Cromwell DA, Edozien LC et al. Third- and fourth-degree perineal tears among primiparous women in England between 2000 and 2012: time trends and risk factors. BJOG 2013; 20: 15161525 